\title{
Accelerating Neoproterozoic research through scientific drilling
}

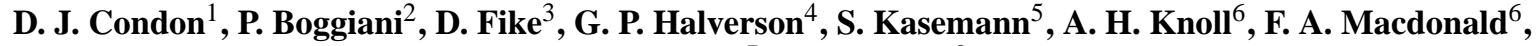 \\ A. R. Prave ${ }^{7}$, and M. Zhu ${ }^{8}$ \\ ${ }^{1}$ NERC Isotope Geoscience Facilities, British Geological Survey, Nottingham, UK \\ ${ }^{2}$ Instituto de Geociências, Universidade de São Paulo, São Paulo, Brazil \\ ${ }^{3}$ Department of Earth \& Planetary Sciences, Washington University, Washington, USA \\ ${ }^{4}$ Department of Earth \& Planetary Sciences, McGill University, Montreal, Canada \\ ${ }^{5}$ Department of Geosciences, University of Bremen, Bremen, Germany \\ ${ }^{6}$ Department of Earth \& Planetary Sciences, Harvard University, Cambridge, USA \\ ${ }^{7}$ Department of Earth \& Environmental Sciences, University of St Andrews, St Andrews, UK \\ ${ }^{8}$ State Key Laboratory of Palaeobiology and Stratigraphy, Nanjing Institute of Geology and Palaeontology, \\ Chinese Academy of Sciences, Nanjing, China
}

Correspondence to: D. J. Condon (dcondon@bgs.ac.uk)

Received: 28 September 2014 - Revised: 20 January 2015 - Accepted: 21 January 2015 - Published: 29 May 2015

\section{Introduction}

The Neoproterozoic Era (1000-541 Ma) and early Cambrian Period (541 to $\sim 520 \mathrm{Ma}$ ) record Earth system changes unlike any other in Earth history (Fig. 1). The start of the Neoproterozoic witnessed the merger of the supercontinent Rodinia, followed by its breakup and dispersal into fragments that form the core of today's continents (Dalziel, 1997; Hoffman, 1991; Li et al., 2008). Climatic states were extreme, with ice sheets extending to the tropics for millions of years followed by ultra-greenhouses; these snowball Earth episodes occurred at least twice (Hoffman, 2009). These tectonic and climatic events occurred in concert with pivotal reorganisations of major biogeochemical cycles potentially accompanied by a rise in oxygen (termed the Neoproterozoic Oxygenation Event, or NOE), and the diversification of eukaryotes followed by the rise of animals (e.g. Erwin et al., 2011; Och and Shields-Zhou, 2012; Fig. 1). Such a concentration of hallmark events in the evolution of our planet is unparalleled. The study of the inter-relations between these events define the forefront of interdisciplinary research between climatology, palaeobiology, geochemistry, geochronology and other fields of geology, yet many outstanding questions remain to be answered (see Sect. 2).

In September 2012 an international conference on the Neoproterozoic Era (evolution, glaciation and oxygenation)
(Rose, 2013) served as the catalyst that initiated discussions to define future strategies to enable Neoproterozoicfocussed research; at the end of this meeting a discussion session was dedicated to this topic and outlining future research priorities. One proposition was to develop a scientific drilling programme for advancing Neoproterozoic research. Subsequently, joint workshop proposals were submitted to the ICDP and the ECORD Magellan+ schemes, resulting in the 2014 workshop at the British Geological Survey, UK, with 44 Earth scientists in attendance from 14 countries. The collective conclusion was the desired ambition to achieve for the Neoproterozoic what the IODP is accomplishing for the Cenozoic: an extensive core archive and associated generation of new, high-quality geochemical, stratigraphic, palaeomagnetic, palaeontological, and geochronological data to address robustly the exciting questions emerging regarding the conditions that transitioned Earth from the Proterozoic into the Phanerozoic. It was also discussed how to use this programme as a catalyst, a transformative mechanism for instigating a network of collaboration through open-access data archiving and information infrastructure development to be populated by the findings of a multidisciplinary, worldwide alliance of Neoproterozoic researchers. Finally, the nature and magnitude of effort involved in scientific drilling means that it often serves as a catalyst for enhanced collaboration 


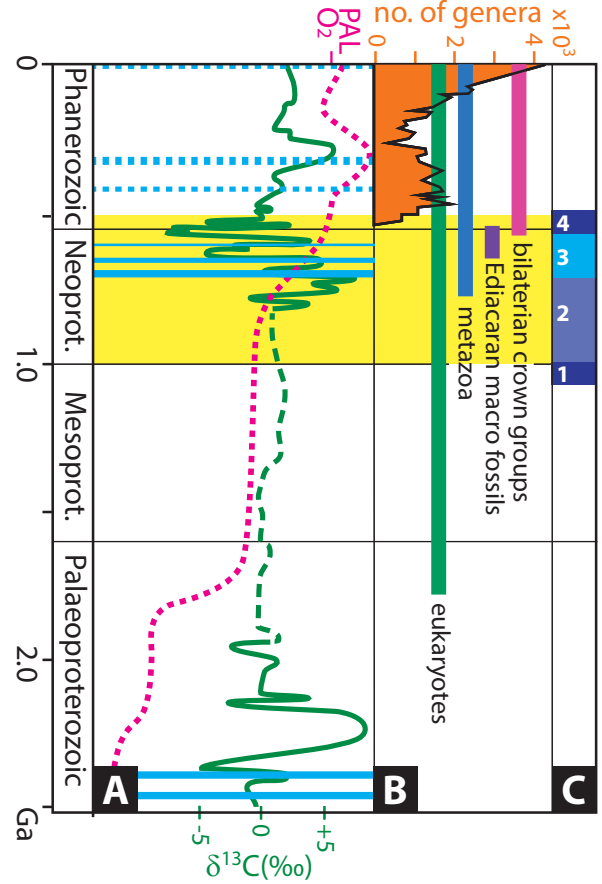

Figure 1. Timeline from the base of the Palaeoproterozoic to present showing the context of the Neoproterozoic to Cambrian rock record targeted for the proposed drilling programme (highlighted in the yellow band). (a) Generalised $\delta^{13} \mathrm{C}$ and $\mathrm{O}_{2}$ (relative to present atmospheric level (PAL)) and major ice age periods shown as horizontal blue bands (solid band signifies globalscale glaciation, dashed band indicates high-latitude glaciation; (b) major evolutionary events; and (c) tectonic events related to the Neoproterozoic-Cambrian time slice (1 - Grenville orogeny; 2 - Rodinia Supercontinent; 3 - Rodinia break-up and drift phase; 4 - Pan-African orogeny). See Halverson et al. (2005), Och and Shields-Zhou (2012), and references therein for data sources.

which then has a positive feedback into the science being done.

The main objectives of the workshop were to

- bring key researchers from a range of countries, and representing a full range of specialities, together to discuss and plan collaboration for advancing research on the Neoproterozoic Era;

- discuss, broker and prioritise key target localities and stratigraphic intervals, and to prioritise strategies for formulating drilling proposals;

- discuss and plan a community-guided, data-management and -archiving environment;

- discuss science themes, organise scientific teams and outline leaders' and members' responsibilities;

- discuss potential sources and models of financial support.
Unlike most other ICDP and ECORD workshop topics, this one was not centred on a single site or collection of sites in one area. Instead it was agreed that the remit of this initiative had to be ambitious: the questions are global in nature hence the drilling strategy had to be commensurate with addressing the questions regarding the time interval spanning $\sim 1000$ to $520 \mathrm{Ma}$ for key successions located on a number of cratons. This ambition of multi-craton coverage for a $\sim 500 \mathrm{Myr}$ time interval is a multi-decade endeavour that will only be realised through numerous coordinated, collaborative projects centred on both core and outcrop archives. In addition to the specific drilling projects, the issues relating to developing and sustaining an overarching initiative were topics for discussion.

\section{Outstanding research questions and problems}

Although advances have been made in the past 2 decades in documenting and interpreting Neoproterozoic events, significant gaps remain: the exact timing of many of the key events is unknown, their durations remain poorly constrained, and techniques for interpreting physical conditions during these events range from satisfying to speculative. Also, it is poorly known how geographically disparate records (Fig. 2) relate to one another in a 4-D framework: are records that are considered related, and therefore correlative, actually synchronous? Combined, these shortcomings create a healthy tension between how existing observations from the rock record inform on the predictions of biospheric and environmental models (both conceptual and numerical) and the data now needed to verify or reject them.

\subsection{Cryogenian inception}

A first-order question is why did the Earth system transition from the relatively climatically stable Mesoproterozoic to an interval of extreme climate and environmental change? A set of relatively stable conditions persisted during the Mesoproterozoic (the so-called "boring billion"), which was characterised by the apparent lack of major geochemical or climatic events. It is unknown what generated the conditions during the Tonian $(\sim 1.0$ to $0.75 \mathrm{Ga})$ that caused a threshold to be crossed and transition into the Cryogenian Period with its severe geochemical and climate fluctuations that framed the origin of animals.

- What were the tectonic and environmental boundary conditions prior to the earliest Cryogenian glaciations? A current favoured hypothesis is that tecono-volcanicweathering processes produced the atmospheric thresholds that resulted in a low-latitude (Snowball Earth) glaciation (Godderis et al., 2003);

- What was the cause and nature of the $\sim 810 \mathrm{Ma}$ Bitter Springs (negative C-isotopic) stage (see Fig. 2)? This 


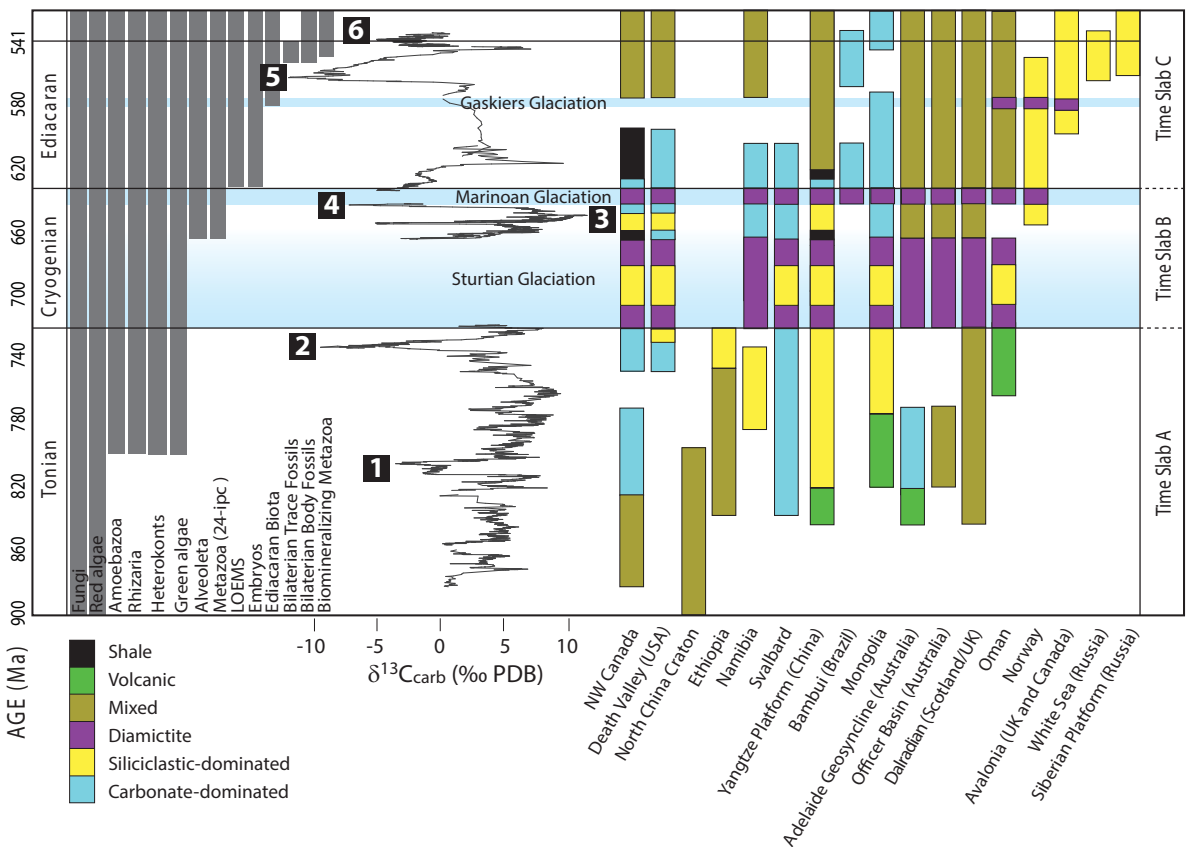

Figure 2. Schematic timeline showing major evolutionary events, a composited $\delta^{13} \mathrm{C}$ curve with numbered isotope anomalies $(1-\mathrm{Bitter}$ Springs; 2 - Islay; 3 - Keele Peak; 4 - Trezona; 5 - Shuram; 6 - BASE) and an approximation of the stratigraphic distribution and dominant lithology type for a number of key Neoproterozoic successions that occur worldwide. Time slabs identified for drilling are shown on the right.

excursion is not associated with evidence for glaciation yet appears to be a global signal. Some workers attribute this to inertial interchange true polar wander (Maloof et al., 2006).

- What caused the radiation of crown group eukaryotes (fungi, algae, etc.), which appears to coincide with the Bitter Springs stage?

\subsection{Timing of environmental perturbations and extreme climate change}

Chemostratigraphic studies worldwide reveal patterns and trends in multi-isotopic systems that have been used to construct the first-order "event" framework depicted in Fig. 2: three major glacial epochs and their temporal association with isotope excursions, geochemical proxies for marine oxygenation, and the fossil record. These have been gleaned from integrating mapping, stratigraphic analysis and geochronology (e.g. Condon et al., 2005; Halverson et al., 2005; Macdonald et al., 2010). This chronology of the Neoproterozoic stratigraphic record, though, is constrained by only a few key radioisotopic dating studies (e.g. Bowring et al., 2007; Condon et al., 2005; Kendall et al., 2004; Macdonald et al., 2010; Rooney et al., 2014) and the exact durations and timing of many of the major climatic and biogeochemical episodes remain unresolved. Building beyond this firstorder picture requires a higher-resolution temporal calibration so that successions from different regions can be com- pared, contrasted and integrated with confidence, and rate dependent processes can be quantified and assessed. Questions that require answers include the following:

- Do the geochemical proxy archives record regional and/or global events, and at what level can synchroneity be demonstrated? How are global signals regionally modulated?

- What controlled the timing of glaciations, their durations and the feedbacks that moderated their reoccurrence, as well as what processes formed the contrasting cap carbonates?

- What is the relationship between large carbon isotope anomalies such as the Islay, Taishir, and Trezona anomalies and the onset of glaciation (Fig. 2)?

- What was the genesis and nature of the largest C-cycle isotopic perturbation in Earth history, the Ediacaran-age Shuram-Wonoka excursion (Fig. 2)?

\subsection{The advent of animals and impact (feedbacks) on environment}

The Earth system houses a suite of interconnected feedback loops and interactions between the coupled biosphereatmosphere-lithosphere systems that influence and control atmosphere-ocean compositions and the viability of life. A question engaging palaeobiologists and geochemists alike is 
what changes in the Earth system presaged the origin and early evolution of animals. Along with that question, many others follow.

- What was the common ancestor of metazoans? What were the first animals and when did they evolve?

- What is the interconnectedness, if any, between the repetitive environmental extremes and changes of Cryogenian time and animal evolution?

- How did the evolution of complex life impact on and respond to changes in ocean and atmospheric chemistry?

Although progress has been made in advancing our collective understanding of these topics (e.g. Boyle et al., 2014; Butterfield, 2011; Erwin et al., 2011; Knoll, 2014; ShieldsZhou and Zhu, 2013), these questions remain the subject of much focussed effort and debate, and a rich area for research. Fundamental to understanding the mechanistic relationship between environment and life is establishing an accurate chronology of global change and the temporal calibration of the fossil record.

\subsection{Geochemical proxies of environmental conditions and the rise of oxygen}

Complementing palaeontological studies, geochemists are detailing systematic patterns in redox sensitive elemental ratios to explore the hypothesis that the advent of animals may have been a consequence of a second global oxygenation event during Ediacaran time, the NOE (e.g. Lyons et al., 2014; Och and Shields-Zhou, 2012; Sahoo et al., 2012).

- Were there Neoproterozoic oxygenation events? And if so, where, when and why?

- What is the relationship(s) between atmospheric oxygen, marine redox, and geochemical proxies, and how do these change over this interval (e.g. associated with the onset of bioturbation)?

- What was the magnitude and tempo of the purported $p \mathrm{O}_{2}$ rise near the end of Ediacaran time? Neither is known and both need to be established.

- Was the rise in $\mathrm{O}_{2}$ a response to a unique geological situation in the Neoproterozoic such that the rate of oxygen consumption decreased (a decrease in the magnitude of oxygen sinks) so that oxygen levels rose via the steady-state photosynthetic production of $\mathrm{O}_{2}$ ?

- Was the rise in $\mathrm{O}_{2}$ the trigger for the advent and expansion of animals, or did animals evolve in response to a biological control such that evolutionary chance enabled development of a genetic toolkit for the growth of large organisms?
These are first-order questions that need to be evaluated through a global-scale data set that is substantially more comprehensive than we have at present. Integrated proxy records of biology and environment connected to precise and accurate stratigraphies are needed to interrogate these issues and determine cause-and-effect relationships.

\section{Developing underpinning data sets}

In addition to the scientific challenges outlined above it was discussed how solving each of these is dependent upon a system of key underpinning data sets.

\subsection{Highly resolved chronostratigraphic framework(s)}

The outstanding scientific questions/issues articulated above are necessarily global in their nature, however (nearly) all of the proxy records we use to address them are necessarily local. Combining local records to develop regional and then global data sets requires the development of resolved chronostratigraphic records that are developed independent of proxy data such that lags and leads assessed and the rates of environmental change quantified can be objectively assessed. The issue of inter-regional correlation is complicated by the nature of the Neoproterozoic stratigraphic record much of what is being sampled are epeiric seas and continental margins, and not necessarily the open oceans. Consequently, the likelihood that local archives reflect a modulated expression of a global signal is increased, making it difficult to assess the importance of local records and their use for global correlation (see below). In contrast to Phanerozoic stratigraphy the Neoproterozoic stratigraphic record is constrained by limited number of radioisotopic constraints, a coarse biostratigraphic zonation based upon limited microand macrofossils (whose range is often poorly constrained), a nascent data set of radiogenic isotope $\left({ }^{87} \mathrm{Sr} /{ }^{86} \mathrm{Sr}\right)$ and an "event stratigraphy" that is based upon an integration of distinct lithologies (e.g. glacial rocks, cap carbonates) integrated with sequence stratigraphy and stable isotope chemostratigraphy (primarily $\delta^{13} \mathrm{C}$ ). The environmental dependence of geochemical data can be assessed by integrating elemental and isotopic data into an objectively constrained depositional framework. The reliance of "event stratigraphy" for correlation is due to a dearth of radioisotopic constraints, and the possibility of circular reasoning has led to a number of correlation schemes being questioned (Kennedy et al., 1998). Over the past 2 decades predictive tests (i.e. reproducibility) and an increasing number of radioisotopic dates have been able to test and inform the "event"-based correlation leading to an evolving ordering/sequencing of events/records (Fig. 2).

The challenge for future research is to develop and build upon the first-order sequencing that has been established. Whilst radioisotopic dating does support certain key events, such as the end of the Marinoan glaciation being globally synchronous (Calver et al., 2013; Condon et al., 2005; Hoff- 
mann et al., 2004), future efforts must focus on developing geochronological-based frameworks for each of the hallmark biogeochemical and climatic events of Neoproterozoic time, as well for the records of second-order events/processes (e.g. timing and duration of unconformities), and integrating those into a worldwide temporally constrained geological framework. Only with such a framework of objectively interlinked geochronology, chemostratigraphy, palaeobiology and geology will the underpinning data become relatable enough to determine timing and rates of processes and events and, hence, enable solid scientific tests of climatic, biospheric evolution, tectonic and ocean-atmosphere redox state models.

\subsection{Baseline petrography and geochemistry}

An agreed key ambition of the workshop group was the need to establish an integrated, petrographic and geochemical database(s) to provide textural (i.e. primary versus diagenetic features), depositional (i.e. facies, environment) and compositional (i.e. bulk rock versus cements/groundmass versus diagenetic mineralogical fingerprinting) context for the isotopic and palaeobiological sampling, all within a 4D stratigraphic framework. In many countries research funding is now awarded on condition of data management plans that aim to ensure that the data produced from the funded research will be archived and, where appropriate, made available to the wider research community, along with the required metadata. Any scientific drilling project that is undertaken will require a defined information and data management plan, including implementation of ICDP's established a drilling information system (DIS) approach. At the workshop there was widespread recognition that these approaches are of great utility for a wide range of data, not only those derived from cores, and the community would be wise to embrace and develop (bespoke) systems for widespread use (i.e. for both core and outcrop derived data). Exciting opportunities exist for developing involvement with burgeoning cyber-infrastructure efforts (e.g. EARTHCUBE - http: //earthcube.org/). Although such efforts require significant initial investment from the community, the potential payback in terms of efficiency and ability to handle large multivariate data sets is exciting. The workshop participants agreed that such open-access data archiving was a key component for sharing information that ranged from the basic, such as petrography (textures, cements, diagenetic fabrics, etc.), to the proxy records deduced from isotopic data sets $\left(\delta^{13} \mathrm{C}, \delta^{18} \mathrm{O}\right.$, ${ }^{87 / 86} \mathrm{Sr}, \delta^{34} \mathrm{~S}$, etc.), to the underpinning geochronology (U$\mathrm{Pb}, \mathrm{Re}-\mathrm{Os}$, etc.).

\section{The need for scientific drilling to accelerate Neoproterozoic research}

Few drilled archives exist for Neoproterozoic Earth system research. Two notable exceptions are Oman (South
Oman Salt Basin) and Australia (Centralian Superbasin) and these resulted in benchmark papers on, for example, the study of S isotopes, biospheric evolution, geochronology, micropalaeontology, and even one of the earliest papers on cap carbonates (e.g. Amthor et al., 2003; Bowring et al., 2007; Eyles et al., 2007; Fike and Grotzinger, 2008; Fike et al., 2006; Kennedy, 1996; Lindsay and Leven, 1996; Logan et al., 1995; Pisarevsky et al., 2001; Walter et al., 2000; Willman et al., 2006). This is prime evidence of the value of drill core for obtaining important data and insights.

Elsewhere, progress in understanding the Neoproterozoic Earth system has been based overwhelmingly on the study of surface outcrops. However, many sections across South America, central Africa, Australia and Russia suffer from various combinations of deep weathering, thick soil and vegetation cover, or minimal outcrop, including being buried beneath younger strata. Even in arid localities with exceptional exposures (Namibia, southwestern USA, Adelaide Fold Belt, northern Ethiopia), vertical continuity of outcrop belts is limited owing to scree-cover and recessive weathering of finegrained intervals (i.e. shales that are of great interest geochemically). This limitation of exposure, combined with a lack of subsurface data, impedes construction of 3-D stratigraphic architectures, and underscores the need for drilling to advance understanding of the Neoproterozoic rock record from both a scientific perspective and enabling accurate assessments of resource potential.

Many geochemical, isotopic and magnetic proxy records are prone to resetting/overprinting by secondary alteration processes, which fosters scepticism about the veracity of those records as time capsules of original depositional conditions. Pristine cores would provide complete rock intervals and minimise the effects of weathering, alteration and surficial contamination, thereby enabling more direct evaluation of diagenetic overprinting and reducing uncertainties about geochemical signals being original or secondary. The workshop highlighted that it was particularly essential to get drill cores for studies that examine fossil biomarkers (Love et al., 2009), and that the technical requirements for obtaining non-contaminated cores are high and will impact the technical drilling requirements for drilling and core archiving. Similar arguments apply to palaeomagnetic studies which would require oriented cores. Having such material to generate proxy records, especially when linked to age models, would be valuable data for assessing the linkages between oceanic oxygenation and the evolution of large mobile animals (including predators) that require high oxygen levels.

An archive consisting of a network of continuous highquality cores providing rocks as unaltered as possible from surface oxidation and weathering, and that can be correlated accurately and precisely between key locations worldwide, was acknowledged as a critical component to address the questions and research highlighted above. Such an archive will enable strategic, and even repeated, high-resolution sampling (e.g. using XRD core scanners) of pristine samples 
of the hallmark intervals of environmental change and major perturbations in biogeochemical cycles (see Figs. 1, 2). When such data are integrated with outcrop-based data sets, it will enable building an unrivalled 3- and 4-D framework to test ideas and advance our understanding of this hallmark era in Earth history. Continued integration of both outcropand core-based records will be required in order to exploit the inherent strengths of each archive type. Based upon our collective experiences, including involvement with the ICDP (e.g. FAR-DEEP, Melezhik et al., 2013), NASA Astrobiology Institute and Agouron Archaean/Palaeoproterozoic scientific drilling projects (e.g. Schröder et al., 2006), we are certain that a set of archives obtained through continental scientific drilling would play a decisive role in helping achieve these goals.

\section{Scientific drilling: a catalyst for enhancing international collaboration}

The obvious motivation for undertaking a scientific drilling programme is the opportunity to obtain high-quality archives from key sections that are otherwise inaccessible or compromised by weathering. In our case, there is another major motivation: the opportunity to construct a robust and efficient information infrastructure system into which data are freely and routinely contributed through a worldwide network of internationally collaborating researchers. The data sets of field observations, palaeontology, geochemistry $\left(\delta^{13} \mathrm{C}, \delta^{18} \mathrm{O}\right.$, $\delta^{34} \mathrm{~S},{ }^{87} \mathrm{Sr} /{ }^{86} \mathrm{Sr}$ as well as various other non-traditional stable isotopes and proxy records), geochronology and palaeomagnetics related to Neoproterozoic research have grown exponentially; these are becoming difficult to manage and manipulate, and the lack of accessible, well-catalogued samples is impeding scientific progress. The workshop created the forum for frank discussions about constructing networks and infrastructure that span beyond a single project. An agreed ambition is to develop information infrastructure(s) which can service the needs of researchers developing and exploiting data from both outcrop and core based studies and, where relevant, build upon related initiatives with overlapping goals (e.g. the EARTHTIME initiative, EARTHCUBE, the Cryogenian and Ediacaran subcommissions of the International Commission on Stratigraphy). In addition to these efforts it was noted that opportunities for advanced training within this community should be developed and exploited at an early stage of any scientific drilling initiative.

\section{Where and what to drill?}

A potential and embryonic organisational structure was discussed during the workshop, one in which research is organised and managed through working groups that have two discreet but overlapping foci: those that are thematically/methodologically focussed (chronology, palaeobiol- ogy, geochemistry, etc.) and those that are time-slice/science focussed (e.g. inception of the Cryogenian, late Ediacaran). A land-based scientific drilling programme is readily tractable for the vast majority of Neoproterozoic successions in that most of the target sections can be recovered with relatively shallow cores (tens to hundreds of metres). This means that the overall objective of the proposed ICDP initiative to obtain global coverage of a $\sim 500 \mathrm{Myr}$ time window is eminently achievable if a sustained effort is made. It needs to be stressed that the objective is well beyond the scope of a single ICDP proposal, rather it will require a sequence of proposals and projects that will collectively span several decades (i.e. akin to IODP). In that spirit, a major effort of the workshop was prioritising and planning prospective drilling sites. Our considerations and deliberations for scientific drilling focused on two key science drivers.

1. What is the research motivation for drilling?

2. Where are the best places to drill to recover records capable of providing new data and advancing our understanding of Neoproterozoic Earth history and resources?

One option discussed was to focus on a single site with a complete enough geological record such that a core would capture numerous key events/intervals. This approach is attractive as the logistics are simpler and has been used to some effect in previous ICDP projects (e.g. FAR-DEEP, Colorado Plateau Drilling Project). However, it is disadvantageous in that it does not allow for assessment of the global versus "local" nature of the events captured and, therefore, may not achieve substantially more than is currently known (except perhaps at a higher resolution and with a stronger primary signal). Consequently, an alternative approach was agreed: to focus on a "time slab" (see below) and carry out drilling in several palaeogeographically disparate (i.e. distinct cratons) but coeval successions. The multi-region approach results in increased logistical complexity but has the distinct advantage that the global expression of events can be assessed in the detail not obtainable from surface outcrops (this approach would be analogous to some of the IODP transect expeditions, e.g. 320/321, Pacific Equatorial Age Transect). Three "time slabs" were identified.

1. Time slab $A$-transition into the Cryogenian $(\sim 900$ to $\sim 730 \mathrm{Ma}$ ). This time slab would cover the extended interval preceding the Cryogenian. The scientific motivation would be to obtain the data to inform on the conditions during which Earth transitioned from the stable Mesoproterozoic into the Cryogenian, including the evolutionary trends in microfossils and testing ideas about the links between LIP volcanism, weathering and true polar wander.

2. Time slab $B$ - base Cryogenian to earliest Ediacaran $(\sim 730$ to $\sim 635 \mathrm{Ma})$. This encompasses broadly the 
Cryogenian interval with its two major phases of global glaciation, the Sturtian $(\sim 710$ to $\sim 660 \mathrm{Ma})$ and Marinoan $(\sim 645$ to $\sim 635 \mathrm{Ma})$, and intervening interglacial phase. The targeted intervals would include the latter and the strata immediately preceding and post-dating the glaciations, but the thick glacial rocks themselves would not be drilled (Fig. 2).

\section{Time slab $C$ - base Ediacaran to early Cambrian} $(\sim 635$ to $\sim 520 \mathrm{Ma})$. This would cover the period from the end of the Marinoan glaciation through to the Cambrian explosion, encompassing the interval of time containing the fossil record of animal evolution and the marked transformation of global biogeochemical systems (i.e. oxygenation).

Key targets identified for initial targeting focussed on time slab $\mathrm{C}$ and included those in southern China, Brazil and western Russia to build high-resolution records that can be integrated within a resolved chronostratigraphic framework as each of these regions has demonstrated that it is amenable to radioisotopic dating, thus, enabling the integration of regional records to build a global picture. However, the workshop participants also agreed that this was only the initial step in constructing the backbone for future drilling and integrating records worldwide. As the research and drilling programme develops, it is likely that these time slabs will be further subdivided and individual projects more clearly defined.

\section{Beyond a scientific drilling initiative}

Whilst bringing a subset of the community together to discuss a plan for scientific drilling, the workshop also provided the forum to discuss the development of efforts that transcend the work based upon drill cores. Integration with outcrop-derived data is critical, as these data will be used to cite and contextualise the core-based records. Outlined above (Sects. 3-5) are the drivers and justifications for scientific drilling of Neoproterozoic strata to overcome the drawbacks imposed by deep weathering and lack of outcrop; in places less compromised by such shortcomings research will continue to focus on outcrop studies. Obviously, cores will not directly enhance study of the taphonomy of Ediacaran macrofossils (which require extensive bedding plane exposures), but they will enable a far more detailed and thorough documentation of the strata encasing those intervals, including high-resolution sampling for proxy data. Furthermore, as per the hydrocarbon industry, a 3-D network of cores will provide the geometric control to undertake basin-scale reconstructions and thereby more fully assess and develop continental margins and their fringing basinal depositional frameworks, tectonic models and their attendant regional to global palaeogeographies, as well as an integrated suite of age models to construct rates of accommodation space genesis and the durations and magnitudes of unconformities from basin to basin.

Not all of the workshop discussion time was taken up with academic research objectives. The research community is well aware of the resource potential of many Neoproterozoic successions, particularly hydrocarbons (Craig et al., 2013), and strata-bound mineral deposits (these are numerous but examples include economic deposits of $\mathrm{Au}, \mathrm{Zn}, \mathrm{Cu}, \mathrm{Fe}, \mathrm{Mn}$ and $\mathrm{P}$ ). The great transgressive sequences above the Neoproterozoic glacial deposits are particularly attractive hydrocarbon targets, and the rift basins that formed during the breakup of Rodinia are very rich in sedimentary exhalative mineral deposits. It was discussed how the proposed initiative may interface with industrial partners, such as through efforts that allow for the academic study of cores obtained by private companies. This is a topic that will require further discussion as it has the potential for the development of new synergies.

\section{Summary}

The workshop was a great success insofar that it initiated discussion and progress towards the development of a scientific drilling research initiative charged with accelerating Neoproterozoic research and identified key locations to focus on for initial drilling efforts. The Neoproterozoic time slice challenges the Earth science community with a hierarchy of questions from the broadly profound - such as why did complex, macroscopic life evolve on this planet some $600 \mathrm{Myr}$ ago, and how likely is it that other Earth-like planets may have experienced the same? - to the more detailed - such as how do different but broadly coeval stratigraphic sections that contain distinctly different proxy records relate to one another, or what was the duration of the Marinoan glacial event? Such first-order questions have been or are being actively addressed; however, these in turn are producing a new set of sophisticated second-order questions, all of which centre on the when, how and why of the biogeochemical conditions and mechanisms that transformed Earth into a planet inhabited by metazoans and oxygenated to the levels required for macroscopic life. Addressing these questions in a timely and efficient manner would benefit from an evolved approach to the required collaborative multidisciplinary research.

It was agreed that a programme of scientific continental drilling for the Neoproterozoic must match in spirit and scope that of the IODP and its key role in advancing understanding of the co-evolution of Cenozoic climate and life. Such a programme will involve multiple drilling projects funded by different sources (e.g. ICDP plus industry, NASA, national research foundations) and engage with as wide a spectrum of the Earth science community as possible, one open to and inclusive of researchers hailing from universities, geological surveys and other national academic agencies/foundations and industry-related research groups. Such an ambitious undertaking will engage the Earth science com- 
munity for a decade and likely longer. The aim would be to have this proposed programme serve as a catalyst for establishing a worldwide alliance of collaborative, integrated scientific research and data archiving that will carry Neoproterozoic research through the next decade and beyond.

Acknowledgements. We gratefully acknowledge financial support from ICDP and ECORD. We thank Nick Swanson-Hysell and an anonymous reviewer for comments on this workshop report.

Edited by: U. Harms

Reviewed by: N. Swanson-Hysell and one anonymous referee

\section{References}

Amthor, J. E., Grotzinger, J. P., Schroder, S., Bowring, S. A., Ramezani, J., Martin, M. W., and Matter, A.: Extinction of Cloudina and Namacalathus at the Precambrian-Cambrian boundary in Oman, Geology, 31, 431-434, 2003.

Bowring, S. A., Grotzinger, J. P., Condon, D. J., Ramezani, J., Newall, M., and Allen, P. A.: Geochronologic constraints of the chronostratigraphic framework of the Neoproterozoic Huqf Supergroup, Sultanate of Oman, Am. J. Sci., 307, 1097-1145, 2007.

Boyle, R. A., Dahl, T. W., Dale, A. W., Shields-Zhou, G. A., Zhu, M., Brasier, M. D., Canfield, D. E., and Lenton, T. M.: Stabilization of the coupled oxygen and phosphorus cycles by the evolution of bioturbation, Nat. Geosci., 7, 671-676, 2014.

Butterfield, N. J.: Animals and the invention of the Phanerozoic Earth system, Trends Ecol. Evol., 26, 81-87, 2011.

Calver, C. R., Crowley, J. L., Wingate, M. T. D., Evans, D. A. D., Raub, T. D., and Schmitz, M. D.: Globally synchronous Marinoan deglaciation indicated by U-Pb geochronology of the Cottons Breccia, Tasmania, Australia, Geology, 41, 1127-1130, 2013.

Condon, D., Zhu, M., Bowring, S., Wang, W., Yang, A., and Jin, Y.: U-Pb ages from the Neoproterozoic Doushantuo formation, China, Science, 308, 5718, p. 95, doi:10.1126/science.1107765, 2005.

Craig, J., Biffi, U., Galimberti, R. F., Ghori, K. A. R., Gorter, J. D., Hakhoo, N., Le Heron, D. P., Thurow, J., and Vecoli, M.: The palaeobiology and geochemistry of Precambrian hydrocarbon source rocks, Mar. Petrol. Geol., 40, 1-47, 2013.

Dalziel, I. W. D.: OVERVIEW: Neoproterozoic-Paleozoic geography and tectonics: Review, hypothesis, environmental speculation, Geol. Soc. Am. Bull., 109, 16-42, 1997.

Erwin, D. H., Laflamme, M., Tweedt, S. M., Sperling, E. A., Pisani, D., and Peterson, K. J.: The Cambrian Conundrum: Early Divergence and Later Ecological Success in the Early History of Animals, Science, 334, 1091-1097, 2011.

Eyles, C. H., Eyles, N., and Grey, K.: Palaeoclimate implications from deep drilling of Neoproterozoic strata in the Officer Basin and Adelaide Rift Complex of Australia; a marine record of wetbased glaciers: Palaeogeography, Palaeoclimatology, Palaeoecology, 248, 291-312, 2007.

Fike, D. A. and Grotzinger, J. P.: A paired sulfate-pyrite delta S34 approach to understanding the evolution of the EdiacaranCambrian sulfur cycle, Geochim. Cosmochim. Ac., 72, 26362648, 2008.
Fike, D. A., Grotzinger, J. P., Pratt, L. M., and Summons, R. E.: Oxidation of the Ediacaran Ocean, Nature, 444, 744-747, 2006.

Godderis, Y., Donnadieu, Y., Nedelec, A., Dupre, B., Dessert, C., Grard, A., Ramstein, G., and Francois, L. M.: The Sturtian "snowball" glaciation: fire and ice, Earth Planet. Sc. Lett., 211, 1-12, 2003.

Halverson, G. P., Hoffman, P. F., Schrag, D. P., Maloof, A. C., and Rice, A. H. N.: Toward a Neoproterozoic composite carbonisotope record, Geol. Soc. Am. Bull., 117, 1181-1207, 2005.

Hoffman, P. F.: Did the Breakout of Laurentia Turn Gondwanaland Inside-Out?, Science, 252, 1409-1412, 1991.

Hoffman, P. F.: Pan-glacial - a third state in the climate system, Geology Today, 25, 100-107, 2009.

Hoffmann, K. H., Condon, D. J., Bowring, S. A., and Crowley, J. L.: U-Pb zircon date from the Neoproterozoic Ghaub Formation, Namibia: Constraints on Marinoan glaciation, Geology, 32, 817820, 2004.

Kendall, B. S., Creaser, R. A., Ross, G. M., and Selby, D.: Constraints on the timing of Marinoan "Snowball Earth" glaciation by Re-187-Os-187 dating of a Neoproterozoic, post-glacial black shale in Western Canada, Earth Planet. Sc. Lett., 222, 729-740, 2004.

Kennedy, M. J.: Stratigraphy, sedimentology, and isotopic geochemistry of Australian Neoproterozoic postglacial cap dolostones: Deglaciation, delta C-13 excursions, and carbonate precipitation, J. Sediment. Res., 66, 1050-1064, 1996.

Kennedy, M. J., Runnegar, B., Prave, A. R., Hoffmann, K. H., and Arthur, M. A.: Two or four Neoproterozoic glaciations?, Geology, 26, 1059-1063, 1998.

Knoll, A. H.: Paleobiological Perspectives on Early Eukaryotic Evolution, Cold Spring Harbor Perspectives in Biology, 6, 1-14, doi:10.1101/cshperspect.a016121, 2014.

Li, Z. X., Bogdanova, S. V., Collins, A. S., Davidson, A., De Waele, B., Ernst, R. E., Fitzsimons, I. C. W., Fuck, R. A., Gladkochub, D. P., Jacobs, J., Karlstrom, K. E., Lu, S., Natapov, L. M., Pease, V., Pisarevsky, S. A., Thrane, K., and Vernikovsky, V.: Assembly, configuration, and break-up history of Rodinia: A synthesis, Precambrian Res., 160, 179-210, 2008.

Lindsay, J. F. and Leven, J. H.: Evolution of a Neoproterozoic to Palaeozoic intracratonic setting, Officer Basin, South Australia, Basin Res., 8, 403-424, 1996.

Logan, G. A., Hayes, J. M., Hieshima, G. B., and Summons, R. E.: Terminal Proterozoic Reorganization of Biogeochemical Cycles, Nature, 376, 53-56, 1995.

Love, G. D., Grosjean, E., Stalvies, C., Fike, D. A., Grotzinger, J. P., Bradley, A. S., Kelly, A. E., Bhatia, M., Meredith, W., Snape, C. E., Bowring, S. A., Condon, D. J., and Summons, R. E.: Fossil steroids record the appearance of Demospongiae during the Cryogenian period, Nature, 457, 718-721, 2009.

Lyons, T. W., Reinhard, C. T., and Planavsky, N. J.: The rise of oxygen in Earth/'s early ocean and atmosphere, Nature, 506, 307315, 2014.

Macdonald, F. A., Schmitz, M. D., Crowley, J. L., Roots, C. F., Jones, D. S., Maloof, A. C., Strauss, J. V., Cohen, P. A., Johnston, D. T., and Schrag, D. P.: Calibrating the Cryogenian, Science, 327, 1241-1243, 2010.

Maloof, A. C., Halverson, G. P., Kirschvink, J. L., Schrag, D. P., Weiss, B. P., and Hoffman, P. F.: Combined paleomagnetic, isotopic, and stratigraphic evidence for true polar wander from 
the Neoproterozoic Akademikerbreen Group, Svalbard, Norway, Geol. Soc. Am. Bull., 118, 1099-1124, 2006.

Melezhik, V. A., Prave, A. R., Fallick, A. E., Kump, L. R., Strauss, H., Lepland, A., and Hanski, E. J.: Volume 1: The Palaeoproterozoic of Fennoscandia as Context for the Fennoscandian Arctic Russia - Drilling Early Earth Project, Springer, Reading the Archive of Earth's Oxygenation, 2013.

Och, L. M. and Shields-Zhou, G. A.: The Neoproterozoic oxygenation event: Environmental perturbations and biogeochemical cycling, Earth-Sci. Rev., 110, 26-57, 2012.

Pisarevsky, S. A., Li, Z. X., Grey, K., and Stevens, M. K.: A palaeomagnetic study of Empress 1A, a stratigraphic drillhole in the Officer Basin: evidence for a low-latitude position of Australia in the Neoproterozoic, Precambrian Res., 110, 93-108, 2001.

Rooney, A. D., Macdonald, F. A., Strauss, J. V., Dudás, F. Ö., Hallmann, C., and Selby, D.: Re-Os geochronology and coupled Os$\mathrm{Sr}$ isotope constraints on the Sturtian snowball Earth, P. Natl. Acad. Sci., 111, 51-56, 2014.

Rose, C.: Online Special: The Neoproterozoic Era - Evolution, Glaciation, Oxygenation, Geoscienctist Online (http://www.geolsoc.org.uk/Geoscientist/Archive/February2013/Online-Special-The-Neoproterozoic-Era-EvolutionGlaciation -Oxygenation), 2013.
Sahoo, S. K., Planavsky, N. J., Kendall, B., Wang, X., Shi, X., Scott, C., Anbar, A. D., Lyons, T. W., and Jiang, G.: Ocean oxygenation in the wake of the Marinoan glaciation, Nature, 489, 546-549, 2012.

Schröder, S., Lacassie, J. P., and Beukes, N. J.: Stratigraphic and geochemical framework of the Agouron drill cores, Transvaal Supergroup (Neoarchean-Paleoproterozoic, South Africa), S. Afr. J. Geol., 109, 23-54, 2006.

Shields-Zhou, G. and Zhu, M.: Biogeochemical changes across the Ediacaran-Cambrian transition in South China, Precambrian Res., 225, 1-6, 2013.

Walter, M. R., Veevers, J. J., Calver, C. R., Gorjan, P., and Hill, A. C.: Dating the 840-544 Ma Neoproterozoic interval by isotopes of strontium, carbon, and sulfur in seawater, and some interpretative models, Precambrian Res., 100, 371-433, 2000.

Willman, S., Moczydłowska, M., and Grey, K.: Neoproterozoic (Ediacaran) diversification of acritarchs - A new record from the Murnaroo 1 drillcore, eastern Officer Basin, Australia, Rev. Palaeobot Palyno., 139, 17-39, 2006. 